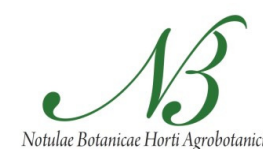

Cluj-Napoca

\title{
In vitro Antitumour Activity of Tomato-Extracted Carotenoids on Human Colorectal Carcinoma
}

\author{
Diana CENARIU ${ }^{1}$, Eva FISCHER-FODOR ${ }^{2}$, Piroska VIRAG ${ }^{2}$, Corina TATOMIR ${ }^{2}$, \\ Mihai CENARIU ${ }^{3 *}$, Emoke PALL ${ }^{3}$, Adela PINTEA ${ }^{4}$, Andrei MOCAN ${ }^{1}$, \\ Ioan SIMON ${ }^{5}$, Gianina CRIŞAN ${ }^{1}$
}

\author{
${ }^{1}$ University of Medicine and Pharmacy "Iuliu Hatieganu" Chij-Napoca, Department of Pharmaceutical Botany, 8 Victor Babes Street, 400012 Cluj-Napoca, \\ Romania;diacenariu@yahoo.com;mocan.andrei@umfchir.ro;gcrisan@umfchj.ro \\ ${ }^{2}$ Institute of Oncology "Prof. Dr. I. Chiricuta", Research Department, 3436 Republicii Street, 400015 Cluj-Napoca, \\ Romania; efischerfodor@yahoo.com; vpiroska@yahoo.com;coratat@yahoo.com \\ ${ }^{3}$ University of Agricultural Sciences and Veterinary Medicine Chij-Napoca, Biotechnology Research Centre, 3-5 Calea Manastur, 400372 Chij-Napoca, \\ Romania; mihai.cenariu@usamvchi.ro(*orrespondingauthor);pallemoke@gmail.com \\ ${ }^{4}$ University of Agricultural Sciences and Veterinary Medicine Cluj-Napoca, Department of Biochemistry, 3-5 Calea Manastur, 400372 Chij-Napoca, \\ Romania;apintea@usamvcluj.ro \\ "University of Medicine and Pharmacy "Iuliu Hatieganu" Cluj-Napoca, Department of Surgery, 18 Republicii Street, 400012 Cluj-Napoca, \\ Romania; isimon@umfcluj.ro
}

\begin{abstract}
The aim of this research was to establish whether all-trans lycopene extracted from fresh and frozen tomatoes is able to inhibit the in vitro proliferation of colon cancer cells, to trigger apoptosis by reactive oxygen species modulation and to reveal its influence on NF-k $\beta$ signalling, through the p65 transcription factor and expression of two TNF receptors: GITR and CD27. The carotenoid extracts containing all-trans lycopene were obtained from fresh (E1) and frozen/thawed (E2) tomatoes (Lycopersicon esculentum Mill.), hybrid 'Menhir' F1. DLD-1 and HT-29 human colon adenocarcinoma cell lines were cocultivated with the two extracts and cytotoxicity, apoptosis, antioxidant activity, reactive oxygen species as well as modulation of NF-k $\beta$ signalling pathway were assessed. Tomato extracts E1 and E2 were able to inhibit colon cancer cell growth in vitro. E2 contained a higher proportion of all-trans lycopene and displayed superior cytotoxicity and a better apoptosis inducing capacity. The two extracts proved antioxidant activity against DPPH radicals and were able to scavenge the reactive oxygen species in the treated tumour cells. This study also showed that lycopene acts mainly through p65 protein and moderately by TNF receptors GITR and CD27 to deactivate the NF-k $\beta$ signalling pathway involved in cancer cell proliferation.
\end{abstract}

Keywords: antioxidant, apoptosis, carotenoid, cytotoxicity, NF-k $\beta$ pathway, tomato, tumour

\section{Introduction}

Colorectal cancer is the third most common neoplasm in the world, with a high rate of incidence and mortality worldwide (Siegel et al., 2014). Colon adenocarcinoma is related to diet (Ravasco et al., 2012), while some natural bioactive compounds such as lycopene proved to have cancer preventing properties (Bohn et al., 2013). Lycopene was intensively studied for its therapeutic potential (Friedman $e t$ al., 2009; Lin et al., 2011; Teodoro et al., 2012; Trejo-Solis et al., 2013) and also included in clinical trials (Breemen and Pajkovic, 2008). All-trans lycopene, a polyunsaturated hydrocarbon, is an abundant carotenoid contained in tomatoes (Gupta et al., 2013); this compound displays remarkable antioxidant properties and antiproliferative effect against various cancer cell types (Choi et al., 2011) based on its capacity to influence the cell cycle (Teodoro et al., 2012) and activate programmed cells death mechanisms (Soares et al., 2013).

Several studies reveal novel mechanistic approaches regarding the lycopene antitumour properties. Lycopene modulates the ROS production (Makon-Sebastien et al., 2014), possesses a robust antioxidant activity due to its singlet oxygen and free radicals quencher ability, and also protects mammalian cells against lipid peroxidation and oxidative DNA damage (Trejo-Solis et al., 2013). Lycopene mediates apoptosis via death receptors, upregulates the anti-apoptotic Bax protein and Fas ligand (Tang et al., 2009) and moreover, downregulates the expression of cyclin D and the antiapoptotic proteins $\mathrm{Bcl}-2$ and $\mathrm{Bcl}-\mathrm{XL}$ blocking the survival of human colon adenocarcinoma cells (Palozza et al., 2007).

The upregulation of nuclear factor kappa $\beta$ (NF-k $\beta$ ) transcription contributes to cancer progression (Linnewiel- 
294

Hermoni et al., 2014). Lycopene was shown to inhibit NF-k $\beta$ activity in various cell lines (Linnewiel-Hermoni et al., 2014; Palozza et al., 2003). This molecule was found to be active in a variety of tumours, and it is a therapeutic target in cancer (Mauro et al., 2009). The efforts to block this transcription factor are focused not only on NF-k $\beta$ itself, but also on other molecules from its signalling pathway; the attenuation of NF$\mathrm{k} \beta$ signalling (Armoza et al., 2013) is linked to vascular endothelial function (Cenariu et al., 2015) and to the tumour necrosis factor TNF-alpha (Makon-Sebastien et al., 2014). The p65 subunit of NF-k $\beta$ is a co-regulator protein, and the activation of NF-k $\beta$ transcription factor can be quantified evaluating the extent of nuclear p 65 translocation (Lafarge et al., 2007).

GITR, the glucocorticoid-induced tumour necrosis factor receptor-related gene TNFSRSF18 from the TNFR superfamily, is expressed in malignant colon cell lines (Baltz et al., 2007) and has an interesting potential for anti-cancer therapy (Nocentini et al., 2012) by tumour growth reduction and immune response enhancement. Another member of the TNFR family which can activate the NF-k $\beta$ pathway (Boursalian et al., 2009) is the transmembrane glycoprotein CD27 or TNFRSF7, which is involved in cell proliferation and survival. The overexpression of CD27 does not influence significantly the NF-k $\beta$ p 65 protein levels (Yamamoto et al., 1998), but binding to its ligand, CD70, it is able to augment significantly the NF-k $\beta$ signalling. Both TNF receptors GITR (Spinicelli et al., 2002) and CD27 (Prasad et al., 1997) display the same apoptosis pathway involving the proapoptotic Siva protein and activate NF-k $\beta$ in the same way by TRAF-2 binding.

There are no previous studies regarding lycopene influence on GITR and CD27 membrane markers.

An important genetic alteration in colorectal cancer is the mutation of Kras gene, which is a member of the Ras subfamily of GTPase proteins, having an important role in cellular signal transduction. Palozza et al. (2010) demonstrated that lycopene treatment in colon cancer changes the cytoplasmatic accumulation of Ras by translocation from cell membranes to cytosol and reduces the Ras-dependent activation of NF-k $\beta$. Previously, the effect of lycopene was described on HT-29 Kras wild type human colon carcinoma (Guil-Guerrero et al., 2011; Palozza et al., 2007; Soares et al., 2013), and also on K-ras mutant tumours (Palozza et al., 2010), but no reports were found until now regarding the lycopene effect on the highly proliferative DLD-1, Kras mutant (Khan et al., 2014) colon adenocarcinoma cell line. The colorectal carcinoma cells constitutively express NF-k $\beta$ p 65 protein (Damnjanovic et al., 2014; Liu et al., 2012; Liu et al., 2014) and GITR (Baltz et al., 2007), therefore the two malignant colon cell populations are suitable to study the implication of these molecules in lycopene antitumour activity.

The aim of this research was to establish whether all-trans lycopene extracted from fresh and frozen tomatoes is able to inhibit the in vitro proliferation of colon cancer cells, to trigger apoptosis by reactive oxygen species modulation and to reveal its influence on NF-k $\beta$ signalling, through the $\mathrm{p} 65$ transcription factor and expression of two TNF receptors: GITR and CD27. The carotenoid extracts containing alltrans lycopene were obtained from fresh (E1) and frozen/thawed
(E2) tomatoes (Lycopersicon esculentum Mill.), hybrid 'Menhir' F1. This hybrid is suitable for cultivation both for production cycle I and II. The fruits weigh 160-190 grams/fruit (average values), with fast and simultaneous ripening ability and a great yield/earliness/taste ratio. Our study proved an adequate total carotenoid content for both extracts (E1-11.76 mg/100 g f.w., E2-8.89 $\mathrm{mg} / 100 \mathrm{~g} \mathrm{f.w}$ ), the main carotenoid being all-trans lycopene (E1-6.46 mg/100 g f.w., E2-6.78 mg/100 g f.w.). The extracts also contained smaller amounts of $\beta$-carotene and $\gamma$ carotene and other minor components, like lycopene epoxide, cis-isomers of lycopene and the colourless carotenoids phytoene and phytofluene. All experiments were performed in triplicate, and repeated three times. IC 50 was assessed with serial dilutions of the extracts that were made taking into consideration the concentration of all-trans lycopene (between $0.5 \mu \mathrm{M}$ and 200 $\mu \mathrm{M}$ all-trans lycopene in culture medium). Subsequently, only the IC50 was used for future investigations. The antitumour activity of the extracts was studied on DLD-1 and HT-29 human colon adenocarcinoma cell lines.

\section{Materials and Methods}

\section{Carotenoid extraction}

The carotenoid extracts were obtained from fresh (E1) and frozen/thawed (E2) tomatoes (Lycopersicon esculentum Mill.), hybrid 'Menhir' F1, organically cultivated in greenhouse tunnels and harvested at full maturity in August 2014.

Tomato samples were extracted three times with a mixture of light petroleum/ethyl acetate/methanol (1:1:1, v/v/v) (Breithaupt and Schwack, 2000). The extracts were transferred in a separation funnel and water was added to allow phase separation. The organic phase was filtered over anhydrous sodium sulphate, evaporated to dry and kept at $-20^{\circ} \mathrm{C}$ until HPLC analysis.

The carotenoid residue was transferred quantitatively in methyl-tert-butyl ether (MTBE), filtered through PTFE 0.45 $\mu \mathrm{m}$ filters and subjected to HPLC-PDA analysis. Separation of carotenoids was performed using a Shimadzu LC20 AT high performance liquid chromatograph (HPLC) with a SPDM20A diode array detector and an YMC C30 column $(24 \mathrm{~cm}$ $\mathrm{x} 4.6 \mathrm{~mm}, 5 \mu \mathrm{m}$ ). The mobile phases were methanol (solvent A) and MTBE (solvent B) and the linear gradient was: at 0 min - $100 \%$ A (0 \% solvent B) to $60 \mathrm{~min}-0 \% \mathrm{~A}(100 \%) 62 \mathrm{~min}$ $100 \% \mathrm{~A}$, followed by equilibration of column for $10 \mathrm{~min}$ (Carillo-Lopez et al., 2014). The flow rate was fixed at 1.0 $\mathrm{ml} / \mathrm{min}$ and the DAD detector was set at $470 \mathrm{~nm}$.

Identification of carotenoids in samples was carried out by comparing the retention time and the UV-Vis absorption spectrum of each compound with those of available standard compounds. Standard compounds $\beta$-carotene and lycopene were provided by LGC Standards, UK. The other compounds were tentatively identified according to their UV-VIS absorption spectra. Calibration curves were made with the standard compounds by plotting peak area against concentration for five concentrations ranging from 1-50 $\mu \mathrm{g} / \mathrm{ml}$.

\section{In vitro testing}

In vitro testing was performed on human tumoural colon cell lines: DLD-1 and HT-29, both purchased from the European Cell Culture Collection. DLD-1 cells were grown in RPMI-1640, 
while HT-29 were cultivated in McCoy's 5 cell culture media; both supplemented with fetal bovine serum (FCS) and glutamine (all media and supplements from Sigma Aldrich, St Louis, MO, USA).

Cells were removed using enzymatic methods at subconfluency, resuspended and seeded into 96-well microplates, about $15 \times 10^{3}$ cells/well in $190 \mu \mathrm{l}$ media, and on 6-well plates, respectively, $2.5 \times 10^{5}$ cells in $2.85 \mathrm{ml}$ media (Nunclon delta surface plates from Thermo Fischer Scientific, Waltham, MA, USA). After 24-hours of incubation, once cells were attached to the surface and the proliferation begun, wells were treated with the extracts and with the reference compound, an all-trans lycopene standard, MW 536.87 (Fluorochem Ltd, Hadfield, UK). The treatment was made using a quantity of $10 \mu$ solution/well in 96-well plates, and $150 \mu \mathrm{l}$ in 6-well plates. The fresh tomatoes (E1) and frozen tomatoes (E2) extracts as well as the all-trans lycopene standard solution were dissolved in tetrahydrofuran (THF, Sigma), obtaining $2 \mathrm{mM}$ all-trans lycopene stock solutions. Stock solutions were diluted in PBS, to obtain serial dilutions for treatment; final concentrations in cell culture media were between $0.5 \mu \mathrm{M}$ and $200 \mu \mathrm{M}$ all-trans lycopene. These serial dilutions were used in order to establish the IC 50. After establishing the IC 50 for each of the extracts as well as for the lycopene standard compound, the following experiments were performed with the IC 50 concentration.

\section{Cytotoxicity}

The cytotoxicity of the compounds was measured in colorimetry using the MTT dye (3-(4,5-dimethylthiazol-2-yl)2,5-diphenyltetrazolium bromide, from Sigma Aldrich), following a protocol described before (Fischer-Fodor et al., 2014). In living cells, the MTT is transformed into insoluble formazan as a result of the mitochondrial enzymatic activity; formazan crystals were solubilized in dimethylsulphoxyde (Titolchimica, Italy), and the 96-well plates were measured with a Synergy 2.0 microplate reader (from BioTek Company, Winooski, USA) at $570 \mathrm{~nm}$ wavelength. Three independent measurements were performed for every compound, on both cell lines. The absorbance values reflect the number of viable cells; IC50 values were calculated using the sigmoidal dose-response response relationship, in the $95 \%$ confidence interval. As reference we used THF treated cells, and as positive control the standard aqueous lycopene solution. The toxicity of THF was also measured separately, using the same series of THF concentrations as for extracts solubilisation and compared to untreated cells; none of the cell lines were affected by THF in the studied concentration range (0.001-2.5\% THF in PBS).

\section{Apoptosis}

For apoptosis testing the Alexa Fluor 488 Annexin V/Dead cell apoptosis kit (Invitrogen, Eugene, USA) was employed. Cells treated with the two extracts as well as with the lycopene standard at the IC50 concentration were incubated with fluorescent-labelled Annexin V to mark the apoptotic cells, than treated with propidium iodide (PI) solution to show dead cells, as described before (Miklasova et al., 2014). Samples were analyzed by flow cytometry, with a FACS Canto II Flow cytometer, (BD Biosciences, San Jose, CA, USA) using the 488-nm, blue, aircooled, 20-mW solid-state excitation laser. Fluorescence was detected using the 530/30 filter for Alexa Fluor 488 and 575/26 filter for PI. As reference we used THF treated cells.

\section{Membrane and intracytoplasmatic markers assessment}

For membrane and intracytoplasmatic markers assessment, NF$\mathrm{k} \beta$ primary antibody and PE-labelled secondary antibody were acquired from R\&D Systems, while the Inside Stain kit for cell permeabilization, GITR-APC and CD27-FITC antibodies were from Miltenyi Biotech, Bergisch Gladbach, Germany. Cells treated with the two extracts as well as with the lycopene standard at the IC50 concentration were stained according to the manufacturer's protocol. As reference we used THF treated cells. The samples were analyzed by flow cytometry, with a FACS Canto II Flow cytometer, (BD Biosciences, San Jose, CA, USA) using the 488-nm, blue, aircooled, 20-mW solid state excitation laser and the $530 / 30$ filter for FITC as well as the $585 / 42$ filter for PE. The $633-\mathrm{nm}$, red, $17-\mathrm{mW}$ HeNe excitation laser and the $660 / 20$ filter was used to detect APC.

\section{Antioxidantactivity}

The antioxidant activity was evaluated by the extract's capacity of quenching the 2,2- diphenyl-1-picrylhydrazyl radical (DPPH, from Sigma Aldrich) as described earlier (Tamokou et al., 2013). The phenomenon was highlighted by an oxidoreductive colour change when $5 \mu \mathrm{l}$ of the $2 \mathrm{mM}$ extract reacted with pink-purple $0.0025 \%$ DPPH solution, and was measured at $520 \mathrm{~nm}$ using the UV/VIS spectrophotometer (V-530 equipment from Jasco). The reference median extinction of unreacted DPPH was 0.7817 at $520 \mathrm{~nm}$.

\section{Reactive oxygen species}

Assessment of reactive oxygen species (ROS) in cell cultures treated with the IC50 concentration of the tomato extracts was made using the CM-H2DCFDA General Oxidative Stress Indicator kit (Life Technologies, Carlsbad, Germany). The active compound of the kit, the acetyl ester of 5-(and-6)-chloromethyl2',7'-dichlorodihydrofluorescein diacetate diffuses into the cells, undergoes a transformation into a highly fluorescent $2^{\prime}, 7^{\prime}$ dichlorofluorescein (DCF) adduct, due to the interactions with intracellular esterases and intracellular glutathione oxidation. The treated cells were removed from cell culture plates and washed with phosphate buffered saline (PBS), counted and an equal quantity of $4.5 \times 10^{5} \mathrm{HT}-29$, and $5.5 \times 10^{5} \mathrm{DLD}-1$ cells were subjected to staining. The cells were incubated with $10 \mu \mathrm{M}$ CM-H2DCFDA solution for 30 minutes, and then washed twice with Hepes solution (buffers from Sigma Aldrich). The samples were processed in triplicate; fluorescence measurement at $485 \mathrm{~nm}$ excitation $/ 528 \mathrm{~nm}$ absorption was performed with a Synergy 2 equipment (BioTek Company, Winooski, USA).

\section{Statistical analysis}

Statistical analysis was performed using the GraphPad Prism 5 software (from GraphPad Software, La Jolla, USA). All analyses were performed in triplicate and repeated three times. Data obtained for the two extracts was compared with each other and with that obtained for cells treated only with THF as well as treated with the all-trans lycopene standard. Various statistical tests were performed, as mentioned for each analysis in particular.

\section{Results and Discussion}

\section{Carotenoid composition}

Fresh tomatoes (E1) had a total carotenoid content of 11.76 $\mathrm{mg} / 100 \mathrm{~g}$ fresh weight. The major carotenoid was lycopene, with smaller amounts of $\beta$-carotene and $\gamma$-carotene. Frozen tomatoes (E2) had a total carotenoid content of $8.89 \mathrm{mg} / 100 \mathrm{~g}$, most of 
296

Table 1. Carotenoid composition of fresh and frozen tomatoes

\begin{tabular}{|c|c|c|c|c|}
\hline \multirow[b]{2}{*}{$\begin{array}{c}\text { Peak } \\
\text { no. }\end{array}$} & \multirow[b]{2}{*}{ Compound } & \multirow{2}{*}{$\begin{array}{c}\text { Retention } \\
\text { time } \\
\text { (min) }\end{array}$} & \multirow{2}{*}{$\begin{array}{c}\text { Fresh (E1) } \\
\mathrm{mg} / 100 \mathrm{~g} \\
\text { f.w. }\end{array}$} & \multirow{2}{*}{$\begin{array}{c}\text { Frozen (E2) } \\
\mathrm{mg} / 100 \mathrm{~g} \\
\text { f.w. }\end{array}$} \\
\hline & & & & \\
\hline 1 & $\beta$-Carotene & 28.4 & 3.11 & 0.95 \\
\hline 2 & $\gamma$-Carotene & 39.3 & 1.32 & 0.33 \\
\hline 3 & Lycopene epoxide & 44.3 & 0.25 & 0.18 \\
\hline 4 & All-trans Lycopene & 48.8 & 6.46 & 6.78 \\
\hline 5 & Cis-Lycopene & 49.3 & 0.61 & 0.64 \\
\hline
\end{tabular}
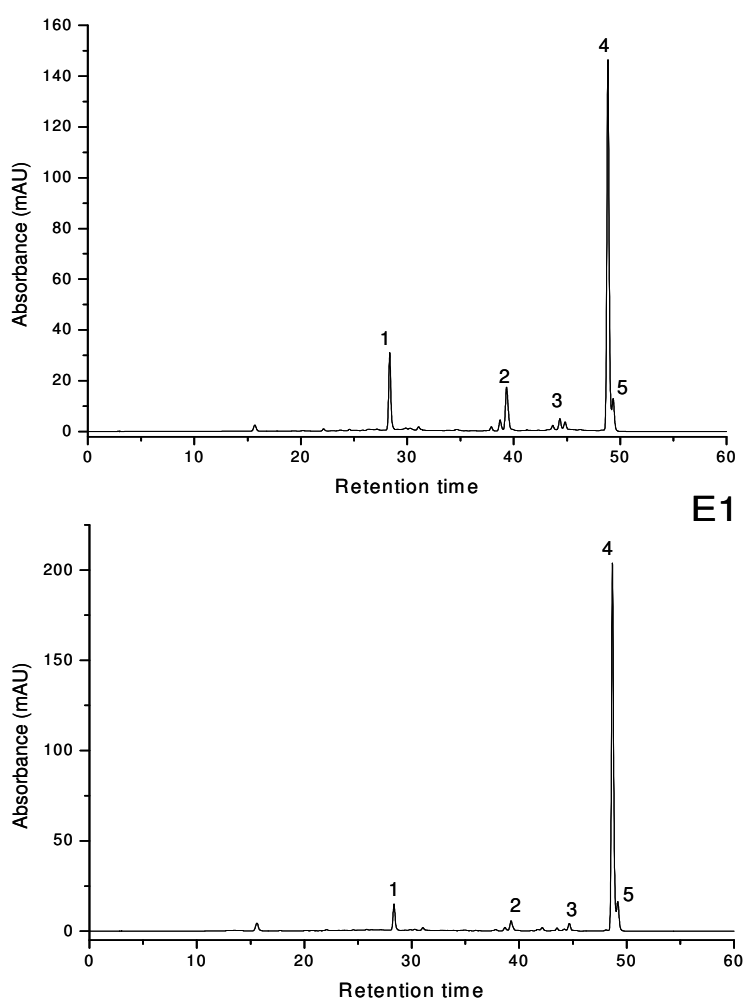

E2

Fig. 1. Chromatograms showing HPLC-PDA separation of carotenoids in fresh (E1) and frozen (E2) tomato extracts. Each peak represents a carotenoid compound. For peak identification see Table 1

Table 2. Half inhibitory concentrations for all-trans lycopene from tomato extractsE1 and E2, and the reference purified compound; median values of 3 independent measurements on DLD-1 and HT-29 colon cancer cell lines. Differences between the two extracts as well as between each of the extracts and the all-trans lycopene standard are statistically significant (unpaired $t$-test, one tailed $\mathrm{p}$ value $<0.05$ ). When THF alone was added, it had no inhibitory effect, similar to untreated cells

\begin{tabular}{lccc}
\hline \multirow{2}{*}{ Parameters } & \multicolumn{3}{c}{ IC50 values $(\mu \mathrm{M})$} \\
\cline { 2 - 4 } & Extract 1 & Extract 2 & All-trans lycopene \\
\hline DLD-1 & & \\
Median value & $65.66^{\mathrm{a}}$ & $37.24^{\mathrm{b}}$ & $9.21^{\mathrm{c}}$ \\
SEM & 4.28 & 1.87 & 1.12 \\
HT-29 & & $19.32^{\mathrm{c}}$ \\
Median value & $455.37^{\mathrm{a}}$ & $242.70^{\mathrm{b}}$ & 0.91 \\
\hline SEM & 11.84 & 6.90 & $\begin{array}{l}\text { Note: On the same row, the same superscript letter following 2 values shows no } \\
\text { statistically significant difference between them, while a different letter signifies a } \\
\text { statistically significant difference (unpaired t-test, one tailed p value }<0.05) .\end{array}$
\end{tabular}

which was also lycopene. Some other minor compounds were present in both extracts, like lycopene epoxide, cis-isomers of lycopene and the colourless carotenoids phytoene and phytofluene (Table 1, Fig. 1).

\section{Cytotoxicity}

Extract 2 (E2) displayed a superior inhibitory effect against tumour cells having lower IC50 values than extract 1 (E1), and both were less toxic than the purified all-trans lycopene solution (Table 2). Statistically significant differences were found between the two extracts as well as between each of the extracts and the alltrans lycopene standard (unpaired t-test, one tailed pvalue $<0.05$ ).

\section{Apoptosis}

The K-ras mutant DLD-1 cells and the K-ras wild type HT29 colon cancer cells were subjected to a 24 -hours treatment with the all-trans lycopene containing extract 1 and 2, an the results were compared with the same concentration of pure lycopene in aqueous solution. The percent of apoptotic cells was better for E1 and E2 when compared to the reference compound, in both cell lines, (one-way analysis of variance, Bonferroni multiple comparison test, $95 \%$ confidence interval, $\mathrm{p}<0.001$, very significant). The same amount of positive reference compound induced more necrosis in both cell lines and the proportion of apoptotic/necrotic cells is better for the extracts (Fig. 2 and 3). Instead, the late apoptotic stage represented by the double coloration was better represented when the standardized lycopene compound was used (one-way analysis of variance, $\mathrm{p}<0.001$ ). This indicates that the transition of cells towards the late apoptotic stages is faster for the pure all-trans lycopene as for E1 and E2, where the same amount of all-trans lycopene is present in a combination with other isomers. Since E2 contains slightly more all-trans lycopene than E1, the overall survival of cells in both cell lines was correlated with the proportion of all-trans lycopene from the extracts. The extracts capacity to trigger apoptosis was more efficient in HT-29 cell line, even if the IC 50 values in HT-29 were noticeably bigger (Table 2), indicating that the all-trans lycopene induced cell death occurred by other cell death mechanisms as well.

\section{The antioxidant activity $(A O A)$}

The antioxidant capacity of the all-trans lycopene-containing extracts was expressed as percent of DPPH radical inhibition, related to unreacted DPPH. AOA values for all-trans lycopene containing extracts E1 and E2 are statistically significant compared with the basal DPPH value, and markedly exceed the reference alltrans lycopene antioxidant properties (Fig. 4). The higher antioxidant capacity of the extracts, compared to pure lycopene, can be due to presence of other carotenoids or tocopherols.

\section{Reactive oxygen species (ROS) reduction}

In DLD-1 cells, extract E2 reduced considerably the ROS level, while E1 had no statistically significant influence; both compounds ROS scavenging capacity was below the pure lycopene (one-way analysis of variance, Bonferroni multiple post-test, $\mathrm{p}<0.01)$. In HT-29 cells the ROS reduction was significant for E1, E2 and the reference lycopene, the extract E2 having similar action as the pure compound (Fig. 5). The ROS reduction was more efficient following the cells treatment with E2, being associated with a higher cytotoxicity (Table 2) and a larger proportion of cells in late apoptosis (Figs. 2 and 3). 
Table 3. The modulation of NF-k $\beta$, GITR and CD27 positive cells within colon cancer cell populations. The percent of PE-stained NF-k $\beta$, APC-GITR and FITC labelled CD27 was calculated by FACS Diva 6.1 software after analyzing 10000 events. All determinations were performed in triplicate; the values shown represent medians of the three determinations, and standard deviation (SD) is shown next to each value. The graphical representation of these results is shown in Figs. 6 and 7

\begin{tabular}{|c|c|c|c|c|}
\hline & THF \% ( \pm SD) & Extract $1 \%( \pm S D)$ & Extract $2 \%( \pm S D)$ & Reference all-trans lycopene $\%( \pm S D)$ \\
\hline \multicolumn{5}{|l|}{ DLD-1 cells } \\
\hline$N F-k \beta^{+}$ & $30.9^{a}( \pm 0.2)$ & $27.8^{\mathrm{b}}( \pm 0.3)$ & $27.7^{\mathrm{b}}( \pm 0.3)$ & $5.1^{c}( \pm 0.2)$ \\
\hline $\mathrm{GITR}^{+}$ & $3.6^{2}( \pm 0.1)$ & $5.4^{\mathrm{a}}( \pm 0.1)$ & $17.5^{\mathrm{b}}( \pm 0.2)$ & $18.7^{\mathrm{b}}( \pm 0.3)$ \\
\hline $\mathrm{CD} 27^{+}$ & $0.2^{\mathrm{a}}( \pm 0.1)$ & $1.5^{\mathrm{a}}( \pm 0.1)$ & $1.8^{\mathrm{a}}( \pm 0.1)$ & $17.1^{\mathrm{b}}( \pm 0.1)$ \\
\hline NF-k $\beta^{+}$GITR $^{+}$ & $21.2^{\mathrm{a}}( \pm 0.2)$ & $43.7^{\mathrm{b}}( \pm 0.3)$ & $29.6^{c}( \pm 0.2)$ & $71.9^{\mathrm{d}}( \pm 0.3)$ \\
\hline NF-k $\beta^{+} \mathrm{CD} 27^{+}$ & $0.3^{\mathrm{a}}( \pm 0.1)$ & $12.5^{\mathrm{b}}( \pm 0.1)$ & $6.0^{c}( \pm 0.2)$ & $74.1^{\mathrm{d}}( \pm 0.2)$ \\
\hline $\mathrm{GITR}^{+} \mathrm{CD} 27^{+}$ & $0.5^{\mathrm{a}}( \pm 0.1)$ & $9.6^{\mathrm{b}}( \pm 0.1)$ & $5.7^{\mathrm{b}}( \pm 0.1)$ & $85.4^{c}( \pm 0.2)$ \\
\hline \multicolumn{5}{|l|}{ HT-29 cells } \\
\hline NF-k $\beta^{+}$ & $19.4^{\mathrm{a}}( \pm 0.1)$ & $8.8^{\mathrm{b}}( \pm 0.1)$ & $13.1^{\mathrm{b}}( \pm 0.1)$ & $33.1^{\mathrm{c}}( \pm 0.3)$ \\
\hline $\mathrm{GITR}^{+}$ & $4.8^{\mathrm{a}}( \pm 0.1)$ & $11.0^{\mathrm{b}}( \pm 0.2)$ & $7.6^{c}( \pm 0.2)$ & $2.8^{\mathrm{d}}( \pm 0.1)$ \\
\hline $\mathrm{CD} 27^{+}$ & $0.0^{\mathrm{a}}( \pm 0.0)$ & $0.0^{\mathrm{a}}( \pm 0.0)$ & $0.0^{\mathrm{a}}( \pm 0.0)$ & $3.1^{\mathrm{b}}( \pm 0.2)$ \\
\hline NF-k $\beta^{+}$GITR $^{+}$ & $6.9^{\mathrm{a}}( \pm 0.1)$ & $5.2^{\mathrm{a}}( \pm 0.3)$ & $5.3^{\mathrm{a}}( \pm 0.1)$ & $21.7^{\mathrm{b}}( \pm 0.4)$ \\
\hline $\mathrm{NF}-\mathrm{k} \beta^{+} \mathrm{CD} 27^{+}$ & $0.0^{\mathrm{a}}( \pm 0.0)$ & $0.1^{\mathrm{a}}( \pm 0.0)$ & $0.0^{\mathrm{a}}( \pm 0.0)$ & $9.1^{b}( \pm 0.2)$ \\
\hline GITR $^{+} \mathrm{CD} 27^{+}$ & $0.0^{\mathrm{a}}( \pm 0.0)$ & $0.0^{\mathrm{a}}( \pm 0.0)$ & $0.0^{\mathrm{a}}( \pm 0.0)$ & $9.4^{\mathrm{b}}( \pm 0.2)$ \\
\hline
\end{tabular}

Note: On the same row, the same superscript letter following 2 values shows no statistically significant difference between them, while a different letter signifies a statistically significant difference (unpaired $t$-test, one tailed p value $<0.05$ ).
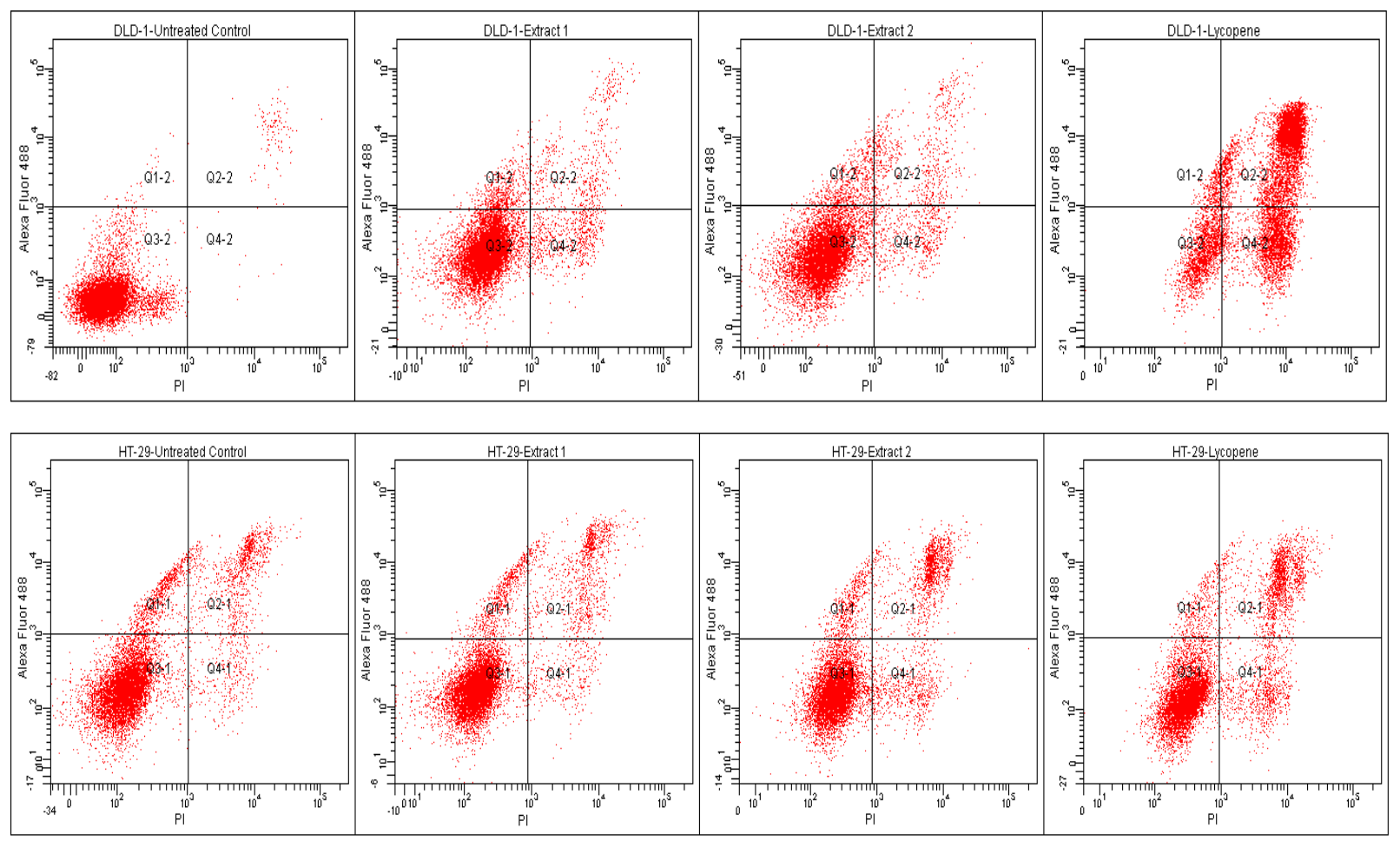

Fig. 2. Histogrames obtained by flow cytometry showing apoptosis versus necrosis in the two colon cancer cell populations: DLD1 (upper row) and HT-29 (lower row)

The upper left quadrand contains apoptotic cells stained with Alexa Fluor 488, while the lower right quadrand contains necrotic cells stained with Propidium Iodide (PI). A fraction of the colon cancer cells display both colorations (upper right quadrant), which denotes that they are in a transition phase towards late apoptosis. Cells shown in the lower left quadrant are viable, negative for both colorations. From left to right: controls, all-trans lycopene-containing extract 1, extract 2 and the reference pure all-trans lycopene

\section{Deactivation of $N F-k \beta$ pathway}

The two extracts (E1 and E2) inhibited the intracellular NF$\mathrm{k} \beta$ expression (Table 3). The inhibitory capacity of E1 and E2 was lower than that of the pure all-trans lycopene in DLD-1 cells, but was superior in HT-29 cells.
In both cell lines, the surface epitope TNFRSF18/GITR was overexpressed following the treatment with E1 and E2 (Fig. 6), although the tendency of double positive NF-k $\beta^{+} \mathrm{GITR}^{+}$cells expression was divergent: enhanced in DLD-1 cells and diminished in HT-29 cells (unpaired t-test, one tailed p value $<0.05)$. 
298

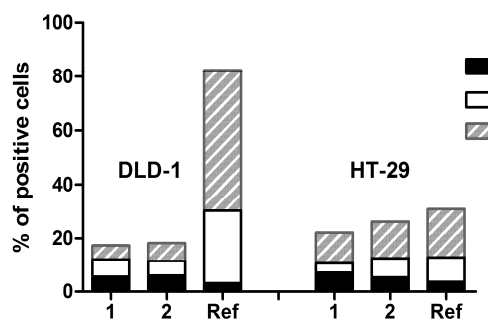

Fig. 3. Grouped representation of the proportion of early and late apoptosis and necrosis which occurs in the colon cancer cells treated with all-trans lycopene from tomato extracts E1 and E2, and the positive reference all-trans lycopene (abbreviated as Ref). All analyses were performed in triplicate. The average values show apoptosis being statistically higher for E1 and E2 when compared to the reference compound, in both cell lines, while the late apoptotic stage and necrosis is more significant in the standardized all-trans lycopene (oneway analysis of variance, Bonferroni multiple comparison test, 95\% confidence interval, $\mathrm{p}<0.001$, very significant)

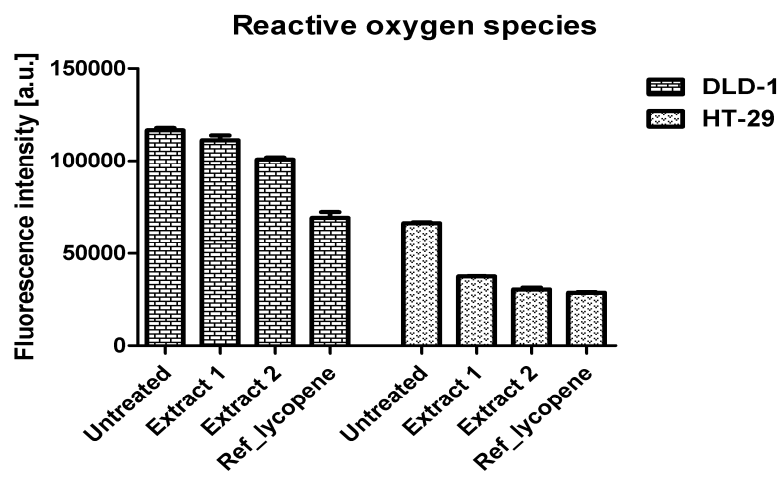

Fig. 5. Reactive oxygen species level in treated colon tumour cells displayed as fluorescence intensity of CM-H2DCFDA. The all-trans lycopene from tomato extracts E1 and E2 was compared to THF treated cells, and with a reference compound, the pure lycopene. All analyses were performed in triplicate. The average values for DLD-1 show that E2 had a statistically significant influence, while E1 did not, and both extracts had a lower capacity to scavenge ROS than pure lycopene. For HT-29, the ROS reduction was statistically significant for $\mathrm{E} 1, \mathrm{E} 2$ and the reference lycopene, E2 being almost as effective as the pure compound (one-way analysis of variance, Bonferroni multiple posttest, $\mathrm{p}<0.01)$

CD27 is not constitutively expressed in colorectal cells; there are few data regarding CD27 gene expression (Fan et al., 2004). We obtained very low basal values in THF treated cells. In DLD-1 cell line, CD27 was overexpressed following both E1 and E2 treatments, accompanied by an increase of double positive NF$\mathrm{k} \beta^{+} \mathrm{CD} 27^{+}$and $\mathrm{GITR}^{+} \mathrm{CD} 27^{+}$cells, without correlations between the data sets (Wilcoxon signed rank test, $\mathrm{p}>0.05$ ). The overexpression of CD27 was related to an increased apoptosis (Fig.6), but there was no statistically significant correlation between the two data sets (nonparametric Spearman correlation, two-tailed p value $>0.5$ ). In HT-29, only the pure all-trans lycopene was able to increase the CD27 expression, together with a strong increase in NF-k $\beta^{+} \mathrm{CD} 27^{+}$and GITR ${ }^{+} \mathrm{CD} 27^{+}$cells ratio (Table 3, Fig. 7).

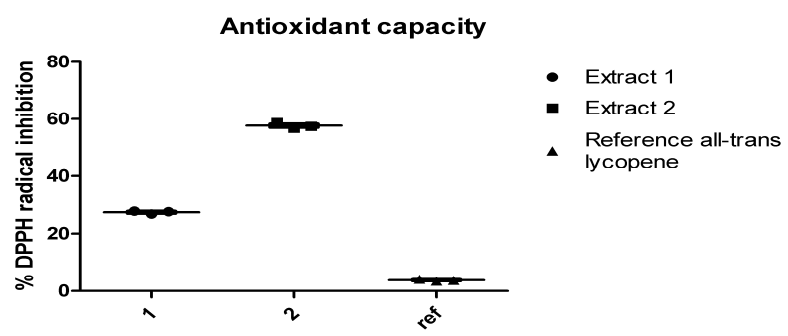

Fig. 4. The all-trans lycopene-containing tomato extracts antioxidant activity measured by DPPH radical inhibitory capacity. All analyses were performed in triplicate. The average values for E1 and E2 are statistically significant compared with the basal DPPH value, and markedly exceed the reference all-trans lycopene antioxidant properties (unpaired t-test, one tailed p value $<0.05$ )

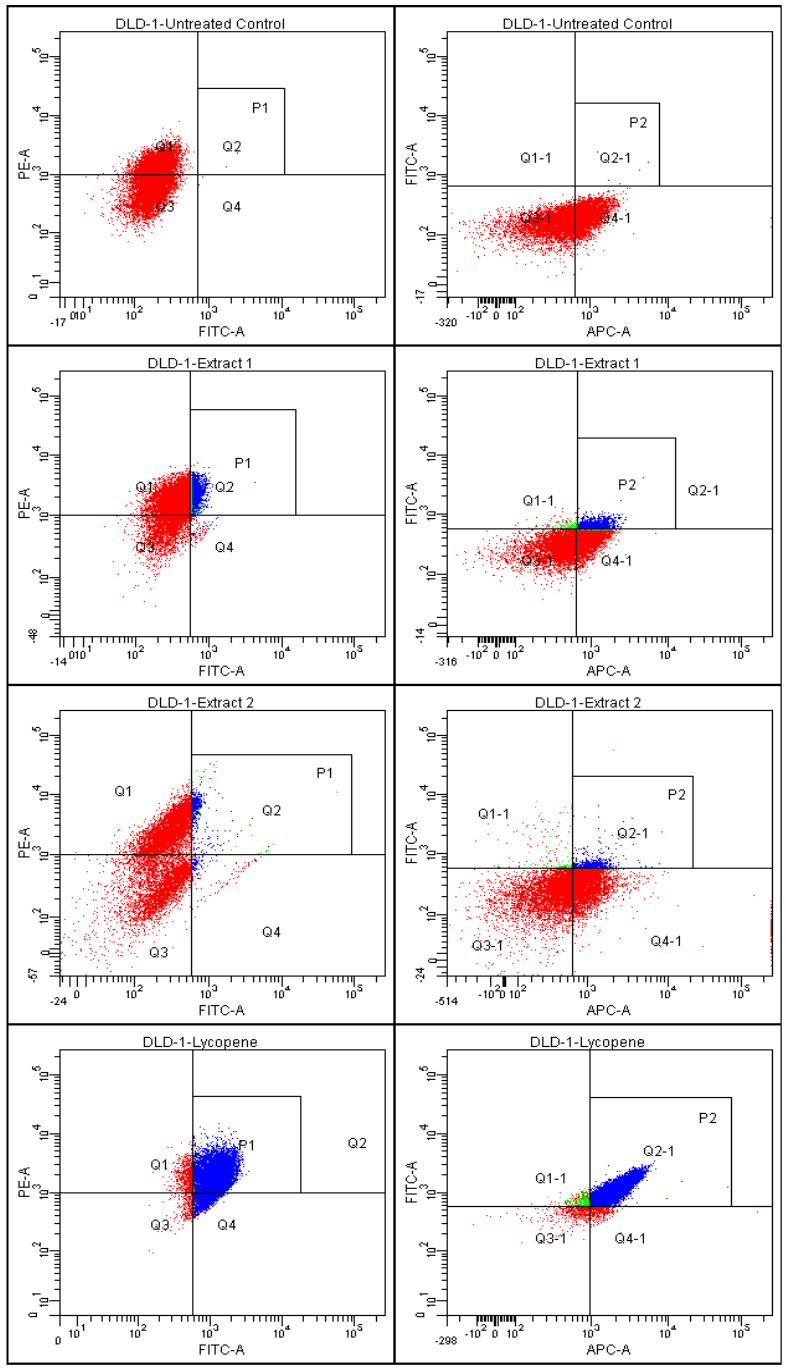

Fig. 6. Distribution of intracellular NF-k $\beta$ and membrane epitopes GITR and CD27 in DLD-1 K-ras mutant cancer cell line after the treatment with E1, E2 and the reference pure all-trans lycopene. From top to bottom: THF treated cells, cells treated with E1, E2 and purified lycopene; fluorescent staining: NF-k $\beta$ PE, GITR APC and CD27 FITC. All analyses were performed in triplicate. For precise values and statistic interpretation, see Table 3 


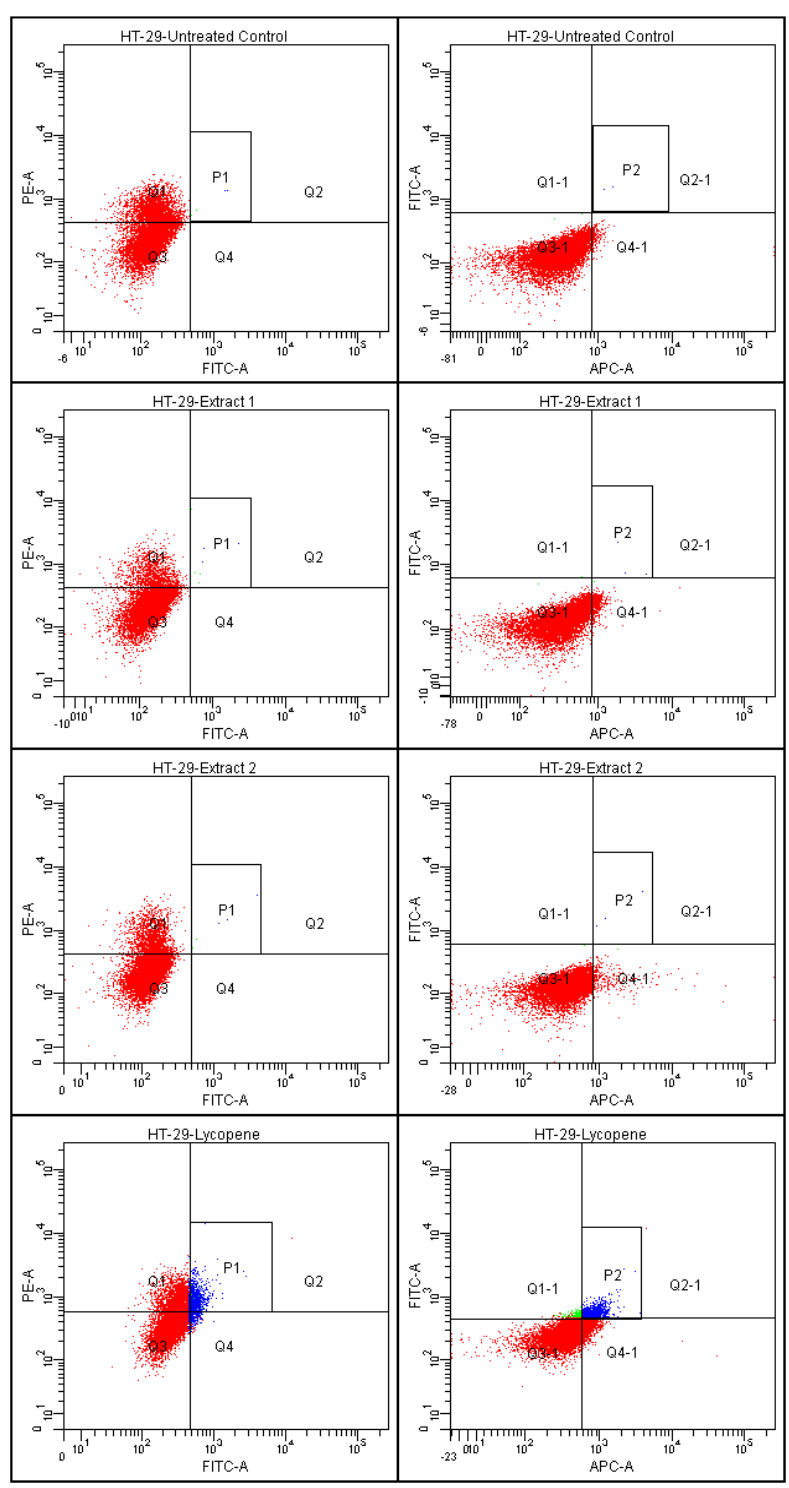

Fig. 7. Expression of NF-k $\beta$, GITR and CD27 positive cells in HT-29 population treated with all-trans lycopene-containing tomato extracts. From top to bottom: THF treated cells, cells treated with E1, E2 and purified lycopene; fluorescent staining: NF-k $\beta$ PE, GITR APC and CD27 FITC. All analyses were performed in triplicate. For precise values and statistic interpretation, see Table 3

No correlation was found between NF-k $\beta$, GITR and CD27 expression in the two colon tumour cell populations; the activated p65 NF- $k \beta$ values were slightly reduced in DLD-1 K-ras mutant cells, despite GITR and CD27 augmentation. The reduction of p 65 NF- $\mathrm{k} \beta$ by E1 and E2 was more pronounced in K-ras wildtype HT-29 cells, where it was accompanied by NF-k $\beta^{+}$GITR $^{+}$ decrease, even if the NF-k $\beta$ GITR ${ }^{+}$cells proportion had a raising tendency.

Thus, the two extracts acted divergently in the two cell lines: in HT-29 cells, E1 and E2 possessed superior capacity to inhibit NF$\mathrm{k} \beta$ signalling than the reference purified compound, while in DLD-1 this trend was opposite. This suggests that the NF-k $\beta$ p 65 activation was not inhibited in the K-ras wild type colon cells, despite better cytotoxicity (Table 2) and more efficient apoptosis triggering (Fig. 3). Other cell death mechanisms were involved in this case, that need further investigation.

The inhibitory effect of lycopene is dose-related (Teodoro et al., 2012) which is in concordance with our findings. Although E2 was obtained from frozen tomatoes, we consider that the freezing process did not interfere with the extract's cytotoxicity or apoptosis inducing ability. It was rather the fact that it contained a slightly higher proportion of all-trans lycopene than E1 that made it display superior cytotoxicity and a better apoptosis inducing capacity.

The K-ras mutant DLD-1 cells proliferation was stronger affected by all-trans lycopene than the K-ras wild type, in concordance with previous studies on HCT-116 cells (Palozza et al., 2010), proving the lycopene interference with Ras-dependent signalling. Despite their common K-ras mutation on codon 13 (G13D), HCT116 and DLD-1 genetic profiles are not identical: the BRCA2 mutation is present only on HCT-116, not on DLD1 (Khan et al., 2014) and they contain different mutation of PIK3CA: HCT116 has an H1047R alteration in exon 20, while DLD-1 contains an E545K alteration in exon 9 (Samuels et al., 2005). Both cell lines are BRAF-wild type, different from HT-29 which displays BRAF, SMAD4, PIK3CA3 (phosphoinositide-3kinase, catalytic, alpha polypeptide) and TP53 mutant protein sequences (Ikediobi, 2008), but no K-ras mutations.

Lycopene reduces the reactive oxygen species (Palozza et al., 2012) in normal, but also in tumour cells, resulting in a dual outcome: ROS reduction protects the tumour cell from DNA damages, and regulates the redox signal in cancer by controlling Nrf2, modulation ROS-production enzymes, MAP kinases and inhibiting transcription factors, such as NF-k $\beta$.

The extracts 1 and 2 inhibited the intracellular NF-k $\beta$ expression, in concordance with the previously communicated data (Armoza et al., 2013; Linnewiel-Hermoni et al., 2014; Mauro et al., 2009; Palozza et al., 2010).

\section{Conclusions}

Tomato extracts E1 and E2 were able to inhibit colon cancer cell growth in vitro; E2 contained a higher proportion of all-trans lycopene and displayed superior cytotoxicity and a better apoptosis inducing capacity. The two extracts proved antioxidant activity against DPPH radicals, and their capacity to scavenge the reactive oxygen species in the treated tumour cells followed the same trend. The all-trans lycopene rich extracts capacity to inhibit intracellular NF-k $\beta$ p 65 protein opens the perspectives of antitumour applications. The concomitant examination of three molecules involved in the NF-k $\beta$ transcription events enlighten that lycopene was able to modulate their expression, in both tumoural cell lines. This study opens new perspectives regarding in vivo studies concerning the antitumoural effect of lycopene and other tomatoextracted carotenoids on colorectal carcinoma.

\section{Acknowledgments}

Dr. Diana Cenariu's work was financed by POSDRU no. 159/1.5/S/136893 grant with title: "Parteneriat strategic pentru creşterea calității cercetării ştiințifice din universitățile medicale prin acordarea de burse doctorale şi postdoctorale DocMed.Net_2.0". 
300

Dr. Adela Pintea's work was supported by a grant from the Romanian National Authority for Scientific Research CNCSUEFISCDI; project number PN-II-ID-PCE-2011-3-0721.

The present work was partially supported by Romanian National Council for Scientific Research in Higher Education Romania through the PN-II-ID-PCE-2011-3-1057 250_2011 Exploratory Research Ideas project.

\section{References}

Armoza A, Haim Y, Bashiri A, Wolak T, Paran E (2013). Tomato extract and the carotenoids lycopene and lutein improve endothelial function and attenuate inflammatory NF- $\kappa \mathrm{B}$ signaling in endothelial cells. Journal of Hypertension 31(3):521-529.

Baltz KM, Krusch M, Bringmann A, Brossart P, Mayer F, Kloss M, Baessler T, Kumbier I, Peterfi A, Kupka S, Kroeber S, Menzel D, Radsak MP, Rammensee HG, Salih HR (2007). Cancer immunoediting by GITR (glucocorticoid-induced TNF-related protein) ligand in humans: NK cell/tumor cell interactions. The FASEB Journal 21(10):2442-2454.

Bohn T, Blackwood M, Francis D, Tian Q, Schwartz SJ, Clinton SK (2013). Bioavailability of Phytochemical Constituents From a Novel Soy Fortified Lycopene Rich Tomato Juice Developed for Targeted Cancer Prevention Trials. Nutrition and Cancer 65(6):919-929.

Boursalian TE, McEarchern JA, Law CL, Grewal IS (2009). Targeting CD70 for human therapeutic use. In: Grewal IS (Ed). Therapeutic Targets of the TNF Superfamily. Springer New York pp 108-119.

Breemen RB, Pajkovic N (2008). Multitargeted therapy of cancer by lycopene. Cancer Letters 269(2):339-351.

Breithaupt DE, Schwack W (2000). Determination of free and bound carotenoids in paprika (Capsicum annuum L.) by LC/MS. European Food Research and Technology 211: 52-55.

Carillo-Lopez A, Yahia EM (2014). Changes in color-related compounds in tomato fruit exocarp and mesocarp during ripening using HPLC-APcI ${ }^{+}$-mass Spectrometry. Journal of Food Science and Technology 51(10):2720-2726.

Cenariu D, Fischer-Fodor E, Virag P, Tatomir C, Pintea A, Cenariu $M$, Mocan A, Crişan G (2015). The in vitro effects of a tomato extract on neoangiogenesis-controlling molecules in colon carcinoma cells. Scientific Papers Animal Science and Biotechnologies 48(1):112-117.

Choi SH, Kim HR, Kim HJ, Lee IS, Kozukue N, Levin CE, Friedman M (2011). Free amino acid and phenolic contents and antioxidative and cancer cell-inhibiting activities of extracts of 11 greenhouse-grown tomato varieties and 13 tomato-based foods. Journal of Agricultural and Food Chemistry 59(24):1280112814 .

Damnjanovic I, Kocic G, Najman S, Stojanovic S, Stojanovic D, Veljkovic A, Conic I, Langerholc T, Pesic S (2014). Chemopreventive potential of alpha lipoic acid in the treatment of colon and cervix cancer cell lines. Bratislava Medical Journal 115(10):611-616.
Fan CW, Chan CC, Chao CC, Fan HA, Sheu DL, Chan EC (2004). Expression patterns of cell cycle and apoptosis-related genes in a multidrug-resistant human colon carcinoma cell line. Scandinavian Journal of Gastroenterology 39(5):464-469.

Fischer-Fodor E, Vălean AM, Virag P, Ilea P, Tatomir C, Imre-Lucaci F, Schrepler MP, Krausz LT, Tudoran LB, Precup CG, Lupan I, Hey-Hawkins E, Silaghi-Dumitrescu L (2014). Gallium phosphinoarylbisthiolato complexes counteract drug resistance of cancer cells. Metallomics 6(4):833-844.

Friedman M, Levin CE, Lee SU, Kim HJ, Lee IS, Byun JO, Kozukue N (2009). Tomatine-containing green tomato extracts inhibit growth of human breast, colon, liver, and stomach cancer cells. Journal of Agricultural and Food Chemistry 57(13):5727-5733.

Guil-Guerrero JL, Ramos-Bueno R, Rodríguez-García I, LópezSánchez C (2011). Cytotoxicity screening of several tomato extracts. Journal of Medicinal Food 14(1-2):40-45.

Gupta P, Bansal MP, Koul A (2013). Evaluating the effect of lycopene from Lycopersicum esculentum on apoptosis during NDEA induced hepatocarcinogenesis. Biochemical and Biophysical Research Communications 434:479-485.

Ikediobi O (2008). Characterization of Cancer Gene Mutations in Human Cancer Cell lines for Correlation with Drug Activity. $\mathrm{PhD}$ Thesis, University of Cambridge.

Khan S, Cameron S, Blaschke M, Moriconi F, Naz N, Amanzada A, Ramadori G, Malik IA (2014). Differential gene expression of chemokines in KRAS and BRAF mutated colorectal cell lines: Role of cytokines. World Journal of Gastroenterology 20(11):2979-2994.

Lafarge S, Hamzeh-Cognasse H, Chavarin P, Genin C, Garraud O, Cognasse F (2007). A flow cytometry technique to study intracellular signals NF-kappaB and STAT3 in peripheral blood mononuclear cells. BMC Molecular Biology 31(8):64.

Lin MC, Wang FY, Kuo YH, Tang FY (2011). Cancer chemopreventive effects of lycopene: suppression of MMP-7 expression and cell invasion in human colon cancer cells. Journal of Agricultural and Food Chemistry 59(20):11304-11318.

Linnewiel-Hermoni K, Motro Y, Miller Y, Levy J, Sharoni Y (2014). Carotenoid derivatives inhibit nuclear factor kappa B activity in bone and cancer cells by targeting key thiol groups. Free Radical Biology and Medicine 75:105-120.

Liu F, Bardhan K, Yang D, Thangaraju M, Ganapathy V, Waller JL, Liles GB, Lee JR, Liu K (2012). NF- $\kappa B$ directly regulates Fas transcription to modulate Fas-mediated apoptosis and tumor suppression. The Journal of Biological Chemistry 287(30):2553025540 .

Liu S, Sun X, Wang M, Hou Y, Zhan Y, Jiang Y, Liu Z, Cao X, Chen P, Liu Z, Chen X, Tao Y, Xu C, Mao J, Cheng C, Li C, Hu Y, Wang L, Chin YE, Shi Y, Siebenlist U, Zhang X (2014). A microRNA 221- and 222-mediated feedback loop maintains constitutive activation of $\mathrm{NF \kappa B}$ and STAT3 in colorectal cancer cells. Gastroenterology 47(4):847-859.

Makon-Sébastien N, Francis F, Eric S, Henri VP, François LJ, Laurent P, Yves B, Serge C (2014). Lycopene modulates THP1 and Caco2 cells inflammatory state through transcriptional and 
nontranscriptional processes. Mediators of Inflammation 2014:507272.

Mauro C, Zazzeroni F, Papa S, Bubici C, Franzoso G (2009). The NF-kappaB transcription factor pathway as a therapeutic target in cancer: methods for detection of NF-kappaB activity. Methods in Molecular Biology 512:169-207.

Miklasova N, Fischer-Fodor E, Miklas R, Kuckova L, Kozisek J, Liptaj T, Soritau O, Valentova J, Devinsky F (2014). Synthesis and characterization of new biologically active palladium(II) complexes with (1E,6E)-1,7-bis(3,4-diethoxyphenyl)-1,6heptadiene-3,5-dione. Inorganic Chemistry Communications 46:229-233.

Nocentini G, Ronchetti S, Petrillo MG, Riccardi C (2012). Pharmacological modulation of GITRL/GITR system: therapeutic perspectives. British Journal of Pharmacology 165(7):2089-2099.

Palozza P, Catalano A, Simone R, Cittadini A (2012). Lycopene as a guardian of redox signaling. Acta Biochimica Polonica 59(1):2125.

Palozza P, Colangelo M, Simone R, Catalano A, Boninsegna A, Lanza P, Monego G, Ranelletti FO (2010). Lycopene induces cell growth inhibition by altering mevalonate pathway and Ras signaling in cancer cell lines. Carcinogenesis 31(10):1813-1821.

Palozza P, Serini S, Boninsegna A, Bellovino D, Lucarini M, Monastra G, Gaetani S (2007). The growth-inhibitory effects of tomatoes digested in vitro in colon adenocarcinoma cells occur through down regulation of cyclin D1, Bcl-2 and Bcl-xL. British Journal of Nutrition 98(4):789-795.

Palozza P, Serini S, Torsello A, Di Nicuolo F, Piccioni E, Ubaldi V, Pioli C, Wolf FI, Calviello G (2003). $\beta$-Carotene Regulates NF$\mathrm{k} \beta$ DNA-Binding Activity by a Redox Mechanism in Human Leukemia and Colon Adenocarcinoma Cells. Journal of Nutrition 133(2):381-388.

Prasad KV, Ao Z, Yoon Y, Wu MX, Rizk M, Jacquot S, Schlossman SF (1997). CD27, a member of the tumor necrosis factor receptor family, induces apoptosis and binds to Siva, a proapoptotic protein. Proceedings of the National Academy of Sciences of the United States of America 94(12):6346-6351.

Ravasco P, Monteiro-Grillo I, Camilo M (2012). Individualized nutrition intervention is of major benefit to colorectal cancer patients: long-term follow-up of a randomized controlled trial of nutritional therapy. The American Journal of Clinical Nutrition 96(6):1346-1353.
Samuels Y, Diaz LA Jr, Schmidt-Kittler O, Cummins JM, Delong L, Cheong I, Rago C, Huso DL, Lengauer C, Kinzler KW, Vogelstein B, Velculescu VE (2005). Mutant PIK3CA promotes cell growth and invasion of human cancer cells. Cancer Cell 7(6):561-573.

Siegel R, DeSantis C, Jemal A (2014). Colorectal cancer statistics, 2014. CA: A Cancer Journal for Clinicians 64(2):104-117.

Soares NC, Teodoro AJ, Oliveira FL, Santos CA, Takiya CM, Junior OS, Bianco M, Junior AP, Nasciutti LE, Ferreira LB, Gimba ER, Borojevic R (2013). Influence of lycopene on cell viability, cell cycle, and apoptosis of human prostate cancer and benign hyperplastic cells. Nutrition and Cancer 65(7):1076-1085.

Spinicelli S, Nocentini G, Ronchetti S, Krausz LT, Bianchini R, Riccardi C (2002). GITR interacts with the pro-apoptotic protein Siva and induces apoptosis. Cell Death and Differentiation 9(12):1382-1384.

Tamokou JD, Chouna JR, Fischer-Fodor E, Chereches G, Barbos O, Damian G, Benedec D, Duma M, Efouet AP, Wabo HK, Kuiate JR, Mot A, Silaghi-Dumitrescu R (2013). Anticancer and antimicrobial activities of some antioxidant-rich cameroonian medicinal plants. PLoS One 8(2):e55880.

Tang FY, Cho HJ, Pai MH, Chen YH (2009). Concomitant supplementation of lycopene and eicosapentaenoic acid inhibits the proliferation of human colon cancer cells. The Journal of Nutritional Biochemistry 20(6):426-434.

Teodoro AJ, Oliveira FL, Martins NB, Maia GA, Martucci RB, Borojevic R (2012). Effect of lycopene on cell viability and cell cycle progression in human cancer cell lines. Cancer Cell International 12(1):36.

Trejo-Solís C, Pedraza-Chaverrí J, Torres-Ramos M, Jiménez-Farfán D, Cruz Salgado A, Serrano-García N, Osorio-Rico L, Sotelo J (2013). Multiple Molecular and Cellular Mechanisms of Action of Lycopene in Cancer Inhibition. Evidence-Based Complementary and Alternative Medicine 2013:705121.

Yamamoto H, Kishimoto T, Minamoto S (1998). NF-kappaB activation in CD27 signaling: involvement of TNF receptorassociated factors in its signaling and identification of functional region of CD27. The Journal of Immunology 161(9):4753-4759. 